\title{
DOS ASPECTOS (IN)CONSTITUCIONAIS DO REGIME PENITENCIÁRIO FEDERAL
}

\author{
THE (UN)CONSTITUTIONAL ASPECTS \\ OF THE FEDERAL PRISON SYSTEM
}

Filippe Augusto dos Santos Nascimento

Defensor Público Federal Doutor em direito. Professor na Universidade Federal do Ceará e Curso Juridico Ouse Saber

filippe_asn@hotmail.com

\section{RESUMO}

O presente artigo trata das origens, do histórico edo desenvolvimento do sistema penitenciário federal no Brasil, bem como analisa as principais normas que existem para a regulação de tal modelo carcerário, realizando uma filtragem constitucional de tais dispositivos, apreciando criticamente as normas, a jurisprudência e a práxis sobre a temática, almejando contribuir com a ainda rara literatura nacional sobre a questão.

Palavras-chaves: Presídio Federal. Regime Penitenciário. Cárcere. Prisão. Inconstitucionalidade. 


\section{ABSTRACT}

This article deals with the origins, history and development of the federal penitentiary system in Brazil, as well as analyzes the main norms that exist for the regulation of such prison model, performing a constitutional analysis of such devices, critically appraising the norms, jurisprudence and praxis on the subject, aiming to contribute to the still rare national literature of this subject.

Key words: Federal Prison. Penitentiary Regime. Prison. Prison. Unconstitutionality.

Data de submissão: 26/05/2017

Data de aceitação: 28/07/2017

\section{SUMÁRIO}

INTRODUÇÃO 1. ASPECTOS CONSTITUCIONAIS DO REGIME NORMATIVO DO SISTEMA PENITENCIÁRIO. CONSIDERAÇÓES FINAIS.

La prisión no es escuela para el pueblo.

(Grafite em uma rua qualquer da Argentina).

\section{INTRODUÇÃO}

Em pleno século XXI, a criminalidade persiste como grave problema a ser enfrentado pelo Brasil. Prevenção, repressão, processo e julgamento necessitam atuar conjuntamente para que o problema possa ser combatido de forma eficaz. Sendo efetiva a luta contra o crime, surge o não menos problemático cárcere e, com este, o paradoxo que lhe é inerente. Nas palavras de Arruda: 
O paradoxo do cárcere, a despeito de secular, ainda subsiste inextricável: preparar o preso para a liberdade sob clausura, em condiçóes de não liberdade, em convivência com pessoas igualmente perturbadas, desajustadas. (...) Nada obstante, a sociedade não pode prescindir da pena privativa de liberdade, do cárcere. Inexiste outro veículo apto a fazer-lhe as vezes. É um mal necessário. Cumpre, sim, reputá-la como derradeiro recurso do Direito Penal, sua ultima ratio. Há de ser reservada aos casos de delinquência grave e de multirreincidência. ${ }^{1}$

A realidade carcerária brasileira, no entanto, encontra-se em uma crise mais grave que a do paradoxo teórico. O sistema penitenciário é uma quimera! As unidades prisionais estaduais não possuem condições mínimas de vida. Não há espaço, não há comida, não há segurança, muitas vezes, não há luz e não há água. O Supremo Tribunal Federal (STF) definiu como estado de coisas inconstitucional, ou seja, "um quadro insuportável e permanente de violação de direitos fundamentais a exigir intervenção do Poder Judiciário de caráter estrutural e orçamentário!”2

Não bastasse isso, conforme assevera René Ariel Dotti, a omissão na construção e na adequada gestão dos presídios alimentou a formação de quadrilhas, que, dos cárceres estaduais, organizam e comandam atentados ${ }^{3}$. Esse contexto provocou, na primeira década deste século, a eclosão de motins, rebeliôes e ataques à população por meio de açóes coordenadas por facçóes existentes dentro dos estabelecimentos penitenciários:

No ano 2001 a facçáo PCC (Primeiro Comando da Capital) realizou uma megarrebelião que paralisou trinta presídios e foi o maior motim já realizado no mundo, com destaques na imprensa nacional e internacional, com manchetes em jornais de países como Estados Unidos, Canadá, França, entre outros. Passado cinco anos, em Maio de 2006 houve nova afronta, onde foram 373 ataques na capital paulista, interior e baixada santista; 82 ônibus queimados, 17 agências bancárias depredadas, 48 mortes e cinquenta feridos dentro do quadro de policiais e agentes penitenciários. Todos atribuídos ao PCC; ainda 304 supostos bandidos mortos pela polícia. Nos meses de Julho e Agosto do mesmo ano os ataques se repetiram com 826 ataques registrados no estado de São Paulo, dos quais 9 policiais foram mortos, mas com 102 supostos integrantes do PCC. ${ }^{4}$

$\overline{1}$ ARRUDA, É. Prisōes Federais. Revista do Tribunal Regional da 1a Regiáo, jul. 2010, p. 2.

2 ADPF 347 MC/DF, rel. Min. Marco Aurélio, 9.9.2015. (ADPF-347)

3 DOTTI, R. A. A trágica colheita dos frutos da omissão. Revista Magister de Direito Penal e Processual Penal, jun./jul. 2006, p. 5.

$4 \quad$ Nota de rodapé de PENTEADO JUNIOR, A. T. O Sistema Penitenciário Federal. Revista Magister de direito penal e processual penal, 2004, p. 4. 
A violência comandada pelas facçóes aterrorizou a população, revelando uma nova face do caos do sistema penitenciário nacional, ${ }^{5}$ sendo elemento desencadeador de medidas mais rígidas nas políticas públicas, na legislação e na jurisprudência referentes ao sistema carcerário. Somando-se a isso, determinados internos passaram a assumir papel de destaque na organização de tais movimentos criminosos, personificando o ocaso do sistema penitenciário pátrio.

Diante desse cenário, durante as campanhas presidenciais de 2002, um pouco mais de um ano após os sangrentos ataques provocados pelo PCC, surge a proposta, apresentada pelo entáo candidato Luís Inácio Lula da Silva, de criação de um complexo de presídios federais de segurança máxima com a promessa de abrigar os líderes dessas facções criminosas.

Com a vitória do candidato, a proposta de campanha foi cumprida, tendo sido construídos quatro presídios federais, que hoje estão em funcionamento, quais sejam: a) no Paraná, o Presídio Federal de Catanduvas; b) em Mato Grosso do Sul, o Presídio Federal de Campo Grande; c) em Rondônia, o Presídio Federal de Porto Velho; d) no Rio Grande do Norte, o Presídio federal de Mossoró. Além desses, ainda havia a previsão de construção de um Presídio Federal no Distrito Federal, que nunca foi levada adiante.

A lógica de tais presídios é simples. Sáo construídos estabelecimentos penais de segurança máxima, com boas instalaçóes para os internos, equipados com tecnologia avançada, pessoal capacitado e bem remunerado, aplicando-se um regime disciplinar diferenciado baseado no rigor para os internos e sob a responsabilidade da União. A adoção de tais medidas, no âmbito federal, apenas revela a falência do sistema estadual, que continua em situaçôes precárias e subumanas, sem investimento público e mal administrado, mas sob o "alento" do sistema federal como "válvula de escape" no caso de alguma rebeliáo.

Não obstante a criação dos presídios federais apenas no início deste novo século, podem

\footnotetext{
$5 \quad$ Fala-se em nova face, posto que o problema carcerário brasileiro certamente sempre existiu. Vale como uma descrição remota o trecho do livro João Miguel da cearense Raquel de Queiroz, escrito na década de 1930, que revela o cenário carcerário daquele período: "Com o seguimento dos dias, o verdadeiro suplício da cadeia - o isolamento e a inação - começo a torturar intensamente o preso. Já ele não aguentava, nas longas horas de cisma, encolhido num canto, concentrado e dormente, tirando vagas fumaças do cachimbo. Já os pequenos detalhes da cela - o ninho de morcegos, a grande aranha preta do teto, as listas amarelas do reboco caiado e as réstias vivas de luz que entravam pela trapeira gradeada - em quase nada o interessavam. Apenas lhe despertava a curiosidade um escrito rabiscado a carváo na parede suja, em grandes letras grossas e informes”. QUEIROZ, Raquel de. João Miguel. São Paulo: Editora Siciliano, 1992. P. 20. Assim sendo, no contexto narrado, houve apenas um estrangulamento do problema dada a facilitaçáo logística de coordenação de operações criminosas por meio de integrantes de facções como Comando Vermelho e PCC a partir do avanço tecnológico (tecnologias móveis por meio de telefones celulares).
} 
ser encontrados comandos normativos mais antigos, que já sinalizavam o interesse estatal na construção de penitenciárias geridas pela União. A Lei de Execução Penal, Lei no . 7.210 , de 1984 , no seu texto original, no artigo $86, \$ 1^{\circ}$, já previa a possibilidade de a União construir estabelecimentos penitenciários sob sua gestão:

Art. $86, \$ 1^{\circ}$. A União Federal poderá construir estabelecimento penal em local distante da condenação para recolher, mediante decisão judicial, os condenados à pena superior a 15 (quinze) anos, quando a medida se justifique no interesse da segurança pública ou do próprio condenado. (Redaçáo original)

Em seguida, em 1990, o artigo $3^{\circ}$ da Lei no ${ }^{\circ}$ 8.072, de 1990 (Lei dos Crimes Hediondos), estabeleceu:

Art. $3^{\circ}$. A União manterá estabelecimentos penais, de segurança máxima, destinados ao cumprimento de penas impostas a condenados de alta periculosidade, cuja permanência em presídios estaduais ponha em risco a ordem ou a incolumidade pública.

Em 2003, já com a eleição do governo petista, a Lei de Execução Penal foi alterada pela Lei $\mathrm{n}^{\circ} .10 .792$, alterando os artigos 52 a 54, 57, 58 e 60 para introduzir o Regime Disciplinar Diferenciado e modificando a previsão dos presídios federais do artigo $86, \$ 1^{\circ}$ :

Art. $86, \$ 1^{\circ}$. A União Federal poderá construir estabelecimento penal em local distante da condenaçâo para recolher os condenados, quando a medida se justifique no interesse da segurança pública ou do próprio condenado.

Com base neste alterado dispositivo legal, a União passou a construir os presídios federais. Ocorre que não havia lei que regulamentasse diretamente a transferência dos presos, bem como a permanência dos internos no sistema federal. Ante o impasse, o Ministério da Justiça sugeriu que o Conselho da Justiça Federal (CJF) editasse uma resolução sobre o assunto até que fosse aprovada uma lei. Tal como noticiado pelo Superior Tribunal de Justiça (STJ):

Devido à inexistência de lei que regulamente a matéria e tendo em vista a proximidade da inauguração dos presídios, o Ministério da Justiça sugeriu que o CJF editasse uma resoluçáo com essa finalidade, até que seja aprovada uma lei. Por essa razão, o texto aprovado estabelece que a vigência da resolução será de apenas um ano, a partir de sua publicação, 'visando provisoriamente ao funcionamento emergencial dos estabelecimentos penais federais.'

\footnotetext{
PUBLICADA resoluçáo do CJF sobre os novos presídios federais. Superior Tribunal de Justiça Brasília, 10 mai. 2006.
} 
A solução sugerida pelo Ministério da Justiça, apesar de esdrúxula, foi adotada pelo CJF, que editou a Resolução no . 502/06 com o prazo de validade de um ano (artigo 7o) até que a lei fosse publicada. Exaurida a vigência da resolução sem a publicação da lei, o Executivo arquitetou outra mirabolante saída normativa para a falta de regulamentação do regime penitenciário federal. O Presidente da República, em descompasso com texto constitucional, publicou o Decreto no 6049 de 27 de fevereiro de 2007.

O referido decreto surge para regulamentar o sistema penitenciário federal, extrapolando o mero caráter regulamentar que é inerente a esta espécie normativa. O decreto foi editado sem a existência de uma lei que autorizasse a regulamentação, com fundamento no artigo 84, IV e VI, "a" da Constituição Federal de 1988 (CF/88), ou seja, afirmando-se como decreto autônomo, o que, na realidade, obviamente, não era.

O decreto autônomo, conforme disposto no artigo 84, VI da CF/88, está previsto de forma muito limitada no direito brasileiro, restringindo-se aos casos de organizaçáo e funcionamento da administração federal, quando não implicar aumento de despesa nem criação ou extinção de órgãos públicos e de extinção de funções ou cargos públicos, quando vagos.

A mera leitura do Decreto no 6049 revela o colossal descompasso entre o que ele estatui e o que pode ser objeto de decreto autônomo. Esta espécie normativa deveria ter se restringido a regular a organização e o funcionamento administrativo dos presídios, já o decreto sob estudo tratou de questóes inerentes ao status libertatis dos internos, impondo direitos, deveres, faltas e sançóes. Desse modo, resta demonstrado que, ipso facto, o Executivo, por meio do Decreto n ${ }^{\circ}$. 6049, legislou de forma autoritária e unilateral, travestindo tal conduta na figura do decreto autônomo.

Somente em 2008, foi publicada a Lei $\mathrm{n}^{\mathrm{o}}$. 11.671/08, dispondo sobre a transferência e inclusão de presos em estabelecimentos penais federais, sendo regulamentada por mais um decreto, o Decreto no. 6877/09, que, repetindo o mau hábito do Executivo, em vários dispositivos, extrapola os limites legais, passando a inovar no mundo jurídico. A Lei 11.671/08 e o Decreto 6877/09 formam o núcleo do regime penitenciário federal, sendo os seus aspectos mais importantes analisados abaixo.

O que se pode notar é que a primeira penitenciária federal só foi inaugurada 22 anos após a primeira previsão legal, o que foi tempo suficiente para uma normatizaçáo bem elaborada sobre o assunto. Não obstante isso, o que se constata é que a regulamentação da matéria 
está marcada por grosseiras inconstitucionalidades, o que será mais bem explorado abaixo.

\section{ASPECTOS CONSTITUCIONAIS DO REGIME NORMATIVO DO SISTE- MA PENITENCIÁRIO FEDERAL}

Analisados os contornos históricos e as questóes constitucionais iniciais, passa-se à análise mais detida dos dispositivos normativos que regulam a transferência, inclusáo e permanência de internos no sistema penitenciário federal. Esses aspectos são tratados, basicamente, pela Lei $\mathrm{n}^{\circ} .11 .671$, de 08 de maio de 2008, e pelo Decreto $\mathrm{n}^{\circ} .6 .877$, de 18 de junho de 2009.

Assim sendo, para iniciar o estudo do regime normativo do sistema penitenciário federal, vale observar o artigo $1^{\circ}$ da Lei ${ }^{\circ} 11.671$ :

Art. $1^{\circ}$. A inclusão de presos em estabelecimentos penais federais de segurança máxima e a transferência de presos de outros estabelecimentos para aqueles obedecerão ao disposto nesta Lei.

O primeiro aspecto que decorre da simples redação do artigo $1^{\circ}$ é que os presídios federais admitem tanto a inclusão direta de internos no sistema federal como transferência de presos de outros estabelecimentos. A relevância deste ponto reside no fato de a lei deixar transparecer que pode haver a inclusão de internos diretamente no sistema penitenciário federal sem necessitar que antes tenham passado pelo sistema penitenciário estadual.

O que se tem observado na prática é existirem alguns casos de recolhimento a estabelecimento penitenciário federal como primeiro ingresso no sistema penitenciário nacional. Um dos mais divulgados casos foi o do colombiano Juan Carlos Abadia, preso dia 7 de agosto de 2007, durante a "Operação Farrapos", tendo sido diretamente recolhido para a Penitenciária Federal de Campo Grande?

$\mathrm{O}$ artigo $2^{\circ}$ da Lei 11.671, por sua vez, estabelece:

Art. $2^{\circ}$. A atividade jurisdicional de execuçáo penal nos estabelecimentos penais federais será desenvolvida pelo juízo federal da seção ou subseção judiciária em que estiver localizado o estabelecimento penal federal de segurança máxima ao qual for recolhido o preso.

A redação do artigo é importante, pois define que a competência para acompanhar a

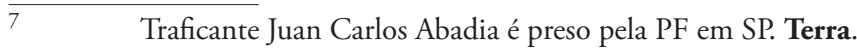


execução penal nos estabelecimentos penitenciários federais é da Justiça Federal, o que se revela importante, quando se observa que o sistema penitenciário federal não abriga apenas condenados por crimes da competência federal, mas também e, principalmente, condenados por crimes de competência estadual.

Nesse sentido, nota-se que a lei tenta impor uma migração de competência da Justiça Estadual para a Justiça Federal, o que se revela uma manifesta agressáo ao texto constitucional. Isso se afirma, pois, como se sabe, que a competência da Justiça Federal é estabelecida de forma taxativa pelo texto constitucional, por meio do rol do artigo 109 . Assim sendo, a mera leitura do citado artigo constitucional demonstra que não existe entre as competências jurisdicionais da Justiça Federal atuação em execução penal, só podendo esse entendimento ser aferido de forma indireta naqueles crimes já expressos no artigo como federais (artigo 109, IV, V, V-A, VI, VII, IX e X da CF/88).

Com efeito, o que se nota é que o texto da Constituição Federal ao definir uma competência subsidiária para a Justiça Estadual (artigos 125 e 126 da CF/88) e não estabelecer entre as competências da Justiça Federal atuação em matéria de execução penal, automaticamente, remeteu àquela Justiça a missão constitucional na matéria agora analisada. Desse modo, o que pretende a Lei no .11 .671 com a redação do artigo $2^{\circ}$ é inserir uma competência para a Justiça Federal por meio de lei ordinária, o que se revela flagrantemente inconstitucional, remetendo o princípio da supremacia constitucional à total insignificância.

Vale frisar que, em mais de uma oportunidade, o STF já afirmou que as competências jurisdicionais são de interpretação restritiva e que não é possível criar competência desta natureza sequer por lei em sentido estrito (salvo expressa autorização constitucional, p. ex., Artigo 109, $\$ 3^{\circ}$ ), sendo necessária, portanto, emenda constitucional para isso. Esse entendimento foi expressamente afirmado, v.g., na Pet 693-AgR, da lavra do Min. Ilmar Galvão, nos seguintes termos: "Não pode, pois, a lei ordinária, como o Código de Processo

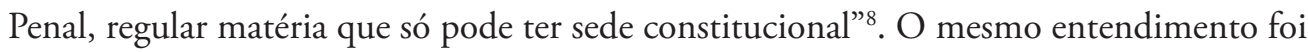
reiterado na ADI 2797/DF que afirmou com todas as letras a exclusividade constitucional da adição de competências jurisdicionais:

EMENTA: (...) IV. Ação de improbidade administrativa: extensão da competência especial por prerrogativa de função estabelecida para

8 Pet 693 AgR, Relator(a): Min. ILMAR GALVÃO, Tribunal Pleno, julgado em 12/08/1993, DJ 01-03-1996 PP-05012 EMENT VOL-01818-01 PP-00014 RTJ VOL-00159-01 PP-00028. 
o processo penal condenatório contra o mesmo dignitário $\left(\$ 2^{\circ}\right.$ do art. 84 do C Pr Penal introduzido pela L. 10.628/2002): declaraçáo, por lei, de competência originária não prevista na Constituição: inconstitucionalidade. 1 . No plano federal, as hipóteses de competência cível ou criminal dos tribunais da União são as previstas na Constituição da República ou dela implicitamente decorrentes, salvo quando esta mesma remeta à lei a sua fixação. 2. Essa exclusividade constitucional da fonte das competências dos tribunais federais resulta, de logo, de ser a Justiça da Uniáo especial em relaçáo às dos Estados, detentores de toda a jurisdiçáo residual. 3. Acresce que a competência originária dos Tribunais é, por definição, derrogação da competência ordinária dos juízos de primeiro grau, do que decorre que, demarcada a última pela Constituição, só a própria Constituiçáo a pode excetuar. 4. Como mera explicitação de competências originárias implícitas na Lei Fundamental, à disposição legal em causa seriam oponíveis as razóes já aventadas contra a pretensão de imposição por lei ordinária de uma dada interpretação constitucional. 5. De outro lado, pretende a lei questionada equiparar a ação de improbidade administrativa, de natureza civil (CF, art. 37, $\left.\$ 4^{\circ}\right)$, à ação penal contra os mais altos dignitários da República, para o fim de estabelecer competência originária do Supremo Tribunal, em relação à qual a jurisprudência do Tribunal sempre estabeleceu nítida distinção entre as duas espécies. 6. Quanto aos Tribunais locais, a Constituiçáo Federal -salvo as hipóteses dos seus arts. 29, X e 96, III -, reservou explicitamente às Constituiçóes dos Estados-membros a definiçáo da competência dos seus tribunais, o que afasta a possibilidade de ser ela alterada por lei federal ordinária(....). (Grifou-se)

A inconstitucionalidade do dispositivo torna-se mais clara quando se ressalta o caráter jurisdicional da execução penal ${ }^{10}$, já confirmado pela moderna doutrina do processo penal, superando o vetusto e ultrapassado entendimento de que a execuçáo penal gozaria de mero caráter administrativo. Defendendo a natureza jurisdicional da execução penal, apresentam-se Dante Busana, Ada Pellegrini e Oscar Xavier de Freitas ${ }^{11}$, por meio das súmulas das Mesas de Processo Penal da Universidade de São Paulo:

Tema: Natureza Jurídica da Execução Penal

Súmula no. 39: A execução penal é atividade complexa que se desenvolve entrosadamente, nos planos jurisdicional e administrativo.

Súmula no. 40: Guarda natureza administrativa a expiação da pena. É objeto do processo de execução, guardando natureza jurisdicional

9 ADI 2797, Relator(a): Min. SEPÚLVEDA PERTENCE, Tribunal Pleno, julgado em 15/09/2005, DJ 19-12-2006 PP-00037 EMENT VOL-02261-02 PP-00250.

10 FERNANDES, A. S. Execuçáo Penal: Aspectos jurídicos, p. 2.

11 MARCÁO, R. Curso de Execuçáo Penal, 2007, p. 3. 
e tutela tendente à efetivação da sanção penal, inclusive com as modificaçóes desta, decorrentes da cláusula rebus sic stantibus, ínsita na sentença condenatória.

Súmula $\mathrm{n}^{\circ}$. 41: Em toda e qualquer execução penal, há pelo menos dois momentos jurisdicionais: seu início e seu encerramento.

Súmula no $n^{\circ}$ 42: No curso de toda e qualquer execução penal, podem, a qualquer momento, ocorrer fenômenos processuais, sempre que o juiz for chamado a julgar, exercendo então a função jurisdicional de julgar. ${ }^{12}$

Assim sendo, ressaltado o caráter jurisdicional da execução penal, falece qualquer argumento no sentido de não ser necessária a presença de competência para execução penal no rol de atribuiçóes jurisdicionais da Justiça Federal. É interessante perceber, no entanto, que a própria lei admite tal caráter, pois afirma que: "a atividade jurisdicional de execuçáo penal nos estabelecimentos penais federais...”. Assim sendo, parece que a própria lei confessa inconstitucionalidade.

Não bastasse o problema de competência, do ponto de vista prático, a mera transferência da execução penal revela-se bastante danosa à defesa dos internos desprovidos de recursos, que, diferente do inicialmente afirmado, são muitos no sistema federal. A transferência de internos sem recursos significa que seus processos criminais tramitaram, em regra, na Justiça Estadual de origem, mas eles estão recolhidos no estabelecimento penitenciário federal, assistidos por um Defensor Público Federal, que tem como atribuição atuar na Justiça Federal, tendo seu papel de atuação na execução do interno prejudicado, já que não pode atuar nos processos estaduais de origem, além de estar a quilômetros de distância

12 GRINOVER, A. P.; GOMES FILHO, A. M.; FERNANDES, A. S. Recursos no Processo Penal, 2011, p. 354. 
deles. $^{13}$

Como se nota, para os internos sem posses, a transferência para o sistema federal revela-se ainda mais prejudicial à defesa no que tange ao acompanhamento processual, pois resta ao defensor que o assiste tomar medidas administrativas, solicitando o apoio das defensorias estaduais do estado de origem, para que acompanhem a defesa dos internos nos processos criminais iniciais.

Por fim, no que se refere ao artigo $2^{\circ}$, merece destaque o fato de a lei tentar aproximar a figura da autoridade judiciária da realidade da penitenciária federal, já que estabelece que a atividade jurisdicional de execução penal nos estabelecimentos penais federais será desenvolvida pelo juízo federal da seção ou subseção judiciária em que estiver localizado o presídio. Nesses termos, o que se pode depreender da lei é que deve ser Juiz-Corregedor do presídio federal um daqueles que atue na vara federal mais próxima do estabelecimento prisional, o que facilita o acompanhamento da execução penal e o cumprimento das normas relativas ao presídio.

O objetivo da norma, evidentemente, é o de aproximação entre o magistrado da execução penal e a vida do presídio sob sua jurisdição, já que, justamente por apreciar o comportamento dos presos e julgar sua vida carcerária (benefícios, regressóes, etc.) necessita estar próximo daquela comunidade carcerária, o que impóe que tal jurisdição seja a mais próxima possível, trate-se de seção ou subseção judiciária.

Infelizmente, esse intelecto normativo não é respeitado nas Seções Judiciárias do Rio Grande do Norte e do Paraná, responsáveis, respectivamente, pelos Presídios Federais

13 O caso pode ensejar, inclusive a atuação da Defensoria enquanto custös vulnerabilis, nos termos expostos por Jorge Bheron Rocha: "Outra hipótese é a atuaçáo nos pedidos de relaxamento feitos por advogado particular em comarcas do interior do estado, estando o acusado preso na capital, cercado de dificuldades para mobilizar sua defesa, limitaçôes lógicas de locomoção e de contato com o mundo exterior[14], inclusive com seu procurador judicial. Em caso assim, o Núcleo da Defensoria Pública que oficia junto à Casa de Privação Provisória de Liberdade Professor Clodoaldo Pinto, em Itaitinga (CE), realizou atendimento ao acusado G.B.S., que contava com causídico particular, cujo processo já se encontrava com instrução encerrada, entretanto aguardando que o juízo intimasse a acusação para a oferta de memoriais escritos. O Núcleo ingressou com petição requerendo a imediata intimação das partes para apresentação dos memoriais a fim de evitar dilatação desnecessária na prisão provisória. Tal intervenção foi acolhida pelo advogado particular constituído que, dialogando processualmente com o que denominou de diligente provocaçáo, reiterou o pedido da Defensoria Pública, o que demonstra perfeita compatibilidade e complementariedade entre as atuaçóes, conforme já alertava Ferrajoli. A atuação diuturna junto aos estabelecimentos prisionais, com as prerrogativas que são asseguradas à instituição e aos seus membros, apresentando as vantagens organizacionais ao demandar[16], a Defensoria Pública pode colaborar com o contraditório substancial, como interveniente, sem com isso dispensar ou substituir o importante papel desempenhado pelo causídico particular, que é o defensor natural.". In: A Defensoria como custös vulnerabilis e a advocacia privada. 
de Mossoró e Catanduvas, visto que há subseções judiciárias federais em Mossoró-RN e Cascavel-PR, que seriam mais próximas aos Presídios Federais antes citados, mas as varas federais responsáveis pela execução penal em tais presídios estão situadas, por ordem, em Natal-RN e Curitiba-PR.

A alegação dos Tribunais Regionais Federais - responsáveis pela instalação das varas - para isso é a questáo de segurança para os juízes, o que não se sustenta seja por descumprimento expresso da legislação; seja por esse argumento não encontrar respaldo na realidade dos outros dois presídios federais (Porto Velho-RO e Campo Grande-MS), que respeitam a lei sem prejuízos à segurança de seus magistrados corregedores; seja, primordialmente, pelos graves problemas à ampla defesa dos apenados, visto que ficam distantes do magistrado, muitas vezes, de seus processos físicos (que, geralmente, chegam físicos dos Estados) e até de advogados.

No âmbito da Defensoria Pública da União, esta questáo obriga uma bipartiçáo de trabalho entre os Defensores Federais com lotação mais próxima dos presídios (Mossoró e Cascavel) e os Defensores Federais com lotação nas Varas da Execução Penal Federal. Os Defensores com atuação mais próxima do Presídio fazem as vistorias, visitas in loco e atendimentos aos internos. Por outro lado, no que tange aos peticionamentos junto às Varas de Execução Federal, há uma distinção histórica entre a DPU no Rio Grande do Norte e no Paraná, pois a DPU-Mossoró-RN, além de realizar o trabalho local no Presídio Federal, também sempre peticionou junto à Vara Federal em Natal, por meio de acordo firmado com o magistrado corregedor, enquanto que, no Paraná, o peticionamento ante à Vara Federal ficou historicamente aos encargos da DPU-Curitiba-PR. Nos dois casos, há flagrante dificuldade no trabalho da Defensoria, pois, no caso da DPU-Mossoró, ficase distante dos autos e do juiz, enquanto que, no caso da DPU-Curitiba, os Defensores ficam distantes dos presos. O simples respeito à legislação, com a mudança da Vara de Execução Federal para a subseção mais próxima do presídio, sanaria todos esses graves problemas à ampla defesa.

$\mathrm{O}$ artigo $3^{\circ}$ da Lei $n^{\circ} .11 .671$ trata do perfil de preso federal:

Art. 3o. Serão recolhidos em estabelecimentos penais federais de segurança máxima aqueles cuja medida se justifique no interesse da segurança pública ou do próprio preso, condenado ou provisório.

A redação do artigo $3^{\circ}$ traz uma norma aberta, baseada em um conceito jurídico 
indeterminado "de interesse da segurança pública", o que fica no campo da discricionariedade do magistrado. Ocorre, todavia, que tal arquitetura legislativa macula nitidamente o princípio da legalidade no que se refere à proibição de incriminaçóes vagas e indeterminadas.

O princípio da legalidade, como se sabe, possui quatro funçóes: a) proibir a retroatividade da lei penal; b) proibir a criação de crimes e penas pelos costumes; c) proibir o emprego de analogia para criar crimes, fundamentar ou agravar penas; d) proibir incriminaçóes vagas e indeterminadas ${ }^{14}$. Assim sendo, diante da limitação de liberdade típica do direito e do processo penal (o que significa restrição a direito fundamental) faz-se imperiosa a existência de normas precisas, não sendo possível existir no direito ou no processo penal normas limitadoras de liberdade que sejam vagas e indeterminadas, o que também revela a inconstitucionalidade do artigo $3^{\circ}$ da Lei $n^{\circ}$. 11.671 .

O Decreto $n^{\circ} .6 .877$, por sua vez, ultrapassando o caráter regulamentar e inovando no mundo jurídico, estabelece:

Art. $3^{\circ}$. Para a inclusão ou transferência, o preso deverá possuir, ao menos, uma das seguintes características:

I - ter desempenhado função de liderança ou participado de forma relevante em organização criminosa;

II - ter praticado crime que coloque em risco a sua integridade física no ambiente prisional de origem;

III - estar submetido ao Regime Disciplinar Diferenciado - RDD;

IV - ser membro de quadrilha ou bando, envolvido na prática reiterada de crimes com violência ou grave ameaça;

$\mathrm{V}$ - ser réu colaborador ou delator premiado, desde que essa condição represente risco à sua integridade física no ambiente prisional de origem; ou

VI - estar envolvido em incidentes de fuga, de violência ou de grave indisciplina no sistema prisional de origem.

Da redação do artigo $3^{\circ}$ do Decreto, afere-se que o referido ato normativo não se conteve em regulamentar a Lei no. 11.671, passando a inovar no mundo jurídico, usurpando

$\overline{14}$ GRECO, R. Curso de Direito Penal: Parte geral, 2009, p. 96. 
o papel da Lei, o que revela a inversão normativa, invalidando o dispositivo. Esse rol cria um verdadeiro "perfil" de preso federal. Da leitura de tal dispositivo, notam-se as consequências (tão nefastas quanto evidentes) para a vida carcerária, processual e social do interno, que, seja por qual razão for, venha a ser, em algum momento, inserido no sistema penitenciário federal.

Em especial, destaca-se, como consequência do enquadramento neste perfil, a chamada superestigmatizaçáo, ou seja, um preconceito social e generalizado contra aquele que é preso federal. Tal estigma é sentido, inclusive, no curso dos processos judiciais. Há a formação de uma jurisprudência hiperinquisitiva contra presos federais, que chega a justificar prisões com excesso de prazo, violaçóes a direitos básicos, tais como sigilo da comunicação com advogados e visitas íntimas, única e exclusivamente, pelo fato de o interno ser do sistema penitenciário federal e náo necessariamente por ter ele cometido fatos graves. Resume bem o ponto Gabriel Cesar dos Santos:

\begin{abstract}
Além de estar eivado de imprecisóes e lacunas na formulação dos diplomas normativos que disciplinam o seu funcionamento, o Sistema Penitenciário Federal viola diversos direitos individuais, gerando danos irreversíveis à vida dos sujeitos que estáo submetidos a ele, na medida em que contribui fortemente para construçâo de um perfil sócio-psicológico que potencializa e reforça a relação daqueles com a criminalidade, consolidando a identidade criminosa e perpetuando a desviação. Nesse contexto, verifica-se a existência de uma "superestigmatizaçáo" do preso federal, já que as próprias hipóteses de federalização da execução indicam, em tese, se tratar dos presos mais perigosos. O processo de formação da identidade desviante é ainda mais pernicioso, pois ao assumir o papel correspondente ao estereótipo de "criminoso federal" que lhe foi atribuído, terá que fazer jus à sua periculosidade quando regressar ao convívio social. ${ }^{15}$
\end{abstract}

Nota-se assim que a simples inclusão de alguém no sistema penitenciário federal, o que não raro ocorre de forma equivocada e sem respeitar os padróes previstos na própria legislação sobre o tema, por si só, já gera efeitos deletérios não só para o interno sair de tal sistema, mas também para o prosseguimento de sua vida processual, carcerária e social. Tal como todo preconceito, a "superestigmatização" decorrente do encarceramento federal cria uma "cegueira" que dificulta o reconhecimento de erros pelo próprio sistema. A ideia de que há de se ser mais rígido com o preso federal por ele ser preso federal acaba por desconsiderar a possibilidade daquele indivíduo - pelos fatos que praticou - sequer dever estar no sistema

$\overline{15}$ SANTOS, G. C. Sistema Penitenciário Federal e a violação dos direitos individuais do preso: uma reflexão crítica sobre os critérios de seleção dos inimigos do estado brasileiro. In: Revista da Defensoria Pública da Uniáo, jan/dez. 2016. p. 330. 
penitenciário federal! Este estigma, ao fim e ao cabo, torna este um direito contra a pessoa e não contra os fatos criminosos praticados, o que acaba fragilizando todos os direitos e garantias mais básicos do indivíduo no curso desses processos.

$\mathrm{O}$ artigo $4^{\circ}$ trata da decisão de inclusão do preso no sistema federal:

Art. $4^{\circ}$. A admissão do preso, condenado ou provisório, dependerá de decisão prévia e fundamentada do juízo federal competente, após receber os autos de transferência enviados pelo juízo responsável pela execução penal ou pela prisão provisória.

$\$ 1^{\circ}$. A execução penal da pena privativa de liberdade, no período em que durar a transferência, ficará a cargo do juízo federal competente.

$\$ 2^{\circ}$. Apenas a fiscalização da prisão provisória será deprecada, mediante carta precatória, pelo juízo de origem ao juízo federal competente, mantendo aquele juízo a competência para o processo e para os respectivos incidentes.

O aspecto interessante do dispositivo acima transcrito é o fato de deixar claro que cabe ao Juiz Federal Corregedor a última palavra no que tange à transferência. Como se verá abaixo, quando da análise do artigo $5^{\circ}$, deve haver uma decisão prévia do juiz da origem sobre a transferência, mediante provocação de um dos legitimados. No caso da decisão prévia da origem ser favorável à transferência, não estará o Juiz Federal vinculado a ela, havendo plena liberdade para o Corregedor, se for o caso, negar a inclusão do preso no sistema federal.

$\mathrm{O}$ artigo $4^{0}$ é importante para afirmar o poder de decisão do Juiz Corregedor. É comum, nos casos de transferência para presídios federais, haver pressão política para forçar transferências que, muitas vezes, apenas buscam aquietar os ânimos da opiniáo pública. Por isso, a lei atribui ao juiz e não às autoridades administrativas a decisão sobre a transferência para o presídio federal, o que é não só um reforço à autoridade das decisōes do magistrado, mas uma garantia ao próprio apenado. Entender de forma diversa, atribuindo às autoridades administrativas a decisão sobre as transferências é fazer o Direito tombar ante ao interesse político da ocasião.

Náo obstante isso, o Superior Tribunal de Justiça vem, lamentavelmente, mitigando a discricionariedade do Juiz Federal Corregedor na matéria, em uma clara jurisprudência contra legem. Prevalece no STJ o entendimento no sentido de que, acaso devidamente motivado pelo Juízo Estadual o pedido de manutenção do preso em presídio federal, não 
cabe ao Magistrado Federal exercer juízo de valor sobre a fundamentação apresentada, mas apenas aferir a legalidade da medida:

AGRAVO REGIMENTAL EM CONFLITO NEGATIVO DE COMPETÊNCIA. JUSTIÇA FEDERAL X JUSTIÇA ESTADUAL. EXECUÇÃO DE PENA. PRORROGAÇÃO DE PERMANÊNCIA DE APENADO EM PRESÍDIO FEDERAL DE SEGURANÇA MÁXIMA. MANUTENÇÃO DAS RAZÓES QUE ENSEJARAM O PEDIDO INICIAL. NECESSIDADE DE GARANTIA DA ORDEM PÚBLICA. POSIÇÃO DE LIDERANÇA DO DETENTO NO COMANDO VERMELHO”. MOTIVAÇÃO LEGAL. ARTS. 3º E 10, $\$$ 1º, DA LEI N. 11.671/2008. IMPOSSIBILIDADE DE JUÍZO DE VALOR DO MAGISTRADO FEDERAL. MERA AFERIÇÃO DA LEGALIDADE DA MEDIDA. COMPETÊNCIA DO JUÍZO FEDERAL.

1. A rejeição da renovação de permanência do apenado em presídio federal autoriza seja suscitado conflito de competência, nos termos do art. $10, \$ 5^{\circ}$, da Lei n. 11.671/2008.

2. Persistindo as razóes que ensejaram a transferência do preso para o presídio federal de segurança máxima, como afirmado pelo Juízo de Direito da Vara de Execuçóes Penais do Estado do Rio de Janeiro/RJ, a renovação da permanência do apenado é providência indeclinável, como medida excepcional e adequada para resguardar a ordem pública. Incidência do art. $3^{\circ}$ do Decreto 6.877/2009, que regulamenta a Lei supramencionada.

3. Prevalece no Superior Tribunal de Justiça o entendimento no sentido de que, acaso devidamente motivado pelo Juízo estadual o pedido de manutençáo do preso em presídio federal, náo cabe ao Magistrado Federal exercer juízo de valor sobre a fundamentaçáo apresentada, mas apenas aferir a legalidade da medida. Ressalva do ponto de vista do Relator. $(. . .)^{16}$

Esse entendimento é de todo equivocado, pois retira do magistrado federal a total cognição judicial sobre quem é e por qual motivo determinados internos estão no Presídio Federal. A experiência nos presídios federais revela que, muitas vezes, as autoridades administrativas e até mesmo judiciárias estaduais buscam se desfazer de presos tidos "por problemáticos". Entenda-se nessa expressão equívoca ("problemático”) toda a sorte de preso que impóe afazeres extras às autoridades locais. Nesse grupo, existem presos com doenças raras, suicidas, ameaçados de morte etc., que, por mais que não sejam necessariamente perigosos

$\overline{16}$ AgR no CC $150.364 /$ RJ, Rel. Ministro REYNALDO SOARES DA FONSECA, TERCEIRA SEÇÃO, julgado em 22/02/2017, DJe 02/03/2017 
para os fins da Lei $n^{\circ}$. 11.671, são enviados para o Presídio Federal, muitas vezes, por razóes diversas da realidade, como uma forma de se eximir do problema que é administrar a vida daquela pessoa. Com esse entendimento do STJ, mesmo que o magistrado federal, Corregedor do Presídio Federal, constate que foi um equívoco a inclusão desse apenado no sistema penitenciário federal, ainda assim, será refém do arbítrio do juiz estadual.

Outro exemplo dessa diminuição da cognição executória do magistrado federal:

A concessão do benefício da progressão de regime ao apenado em presídio federal de segurança máxima fica condicionada à ausência dos motivos que justificaram a transferência originária para esse sistema ou, ainda, à superação de eventual conflito de competência suscitado. Tal entendimento jurisprudencial deriva da interpretação sistemática dos dispositivos legais que norteiam o ingresso no Sistema Penitenciário Federal, os quais demonstram a absoluta incompatibilidade entre os motivos que autorizam a inclusão do preso e os benefícios liberatórios da execução. ${ }^{17}$

Nota-se assim que a jurisprudência do STJ vem trilhando um perigoso caminho, contrário, expressamente, ao artigo $4^{\circ}$ da lei - que, apesar de formalmente inconstitucional, como acima visto, segue presente no ordenamento jurídico, dada a presunção de constitucionalidade das leis - que estabelece que depende de decisão do juízo federal competente o ingresso e, por via de consequência, de saída dos internos do sistema penitenciário federal, diminuindo assim a competência jurisdicional do magistrado federal para tal fim, chegando ao ponto de retirar sua competência para atos típicos da execução penal, como a progressão de regime! Patente absurdo!

$\mathrm{O}$ artigo $5^{\circ}$ da lei $n^{\circ} .11 .671$, por sua vez, trata dos legitimados para pedir a transferência de presos para o sistema federal, estabelece a já citada decisão prévia do juiz da origem sobre a transferência, garante ao interno a assistência por Defensor Público Federal, além de estabelecer algumas outras regras procedimentais:

Art. 5․ São legitimados para requerer o processo de transferência, cujo início se dá com a admissibilidade pelo juiz da origem da necessidade da transferência do preso para estabelecimento penal federal de segurança máxima, a autoridade administrativa, o Ministério Público e o próprio preso.

$\$ 1$. Caberá à Defensoria Pública da União a assistência jurídica ao preso que estiver nos estabelecimentos penais federais de segurança

$\overline{17} \quad \mathrm{CC} \mathrm{n}^{\circ} .125 .871 / \mathrm{RJ}$, Ministro Marco Aurélio Bellizze, Terceira Seção, DJe 7/6/2013. 
máxima.

$\$ 2^{\circ}$. Instruídos os autos do processo de transferência, serão ouvidos, no prazo de 5 (cinco) dias cada, quando não requerentes, a autoridade administrativa, o Ministério Público e a defesa, bem como o Departamento Penitenciário Nacional - DEPEN, a quem é facultado indicar o estabelecimento penal federal mais adequado.

$\$ 3^{\circ}$. A instrução dos autos do processo de transferência será disciplinada no regulamento para fiel execução desta Lei.

$\$ 4^{\circ}$. Na hipótese de imprescindibilidade de diligências complementares, o juiz federal ouvirá, no prazo de 5 (cinco) dias, o Ministério Público Federal e a defesa e, em seguida, decidirá acerca da transferência no mesmo prazo.

$\$ 5^{\circ}$. A decisão que admitir o preso no estabelecimento penal federal de segurança máxima indicará o período de permanência.

$\$ 6^{\circ}$. Havendo extrema necessidade, o juiz federal poderá autorizar a imediata transferência do preso e, após a instrução dos autos, na forma do $₫ 2$ o deste artigo, decidir pela manutenção ou revogação da medida adotada.

$\$ 7^{\circ}$. A autoridade policial será comunicada sobre a transferência do preso provisório quando a autorizaçáo da transferência ocorrer antes da conclusão do inquérito policial que presidir.

Dos dispositivos acima, merece destaque a fixaçáo do rol dos legitimados para solicitar a transferência de internos para o sistema federal, quais sejam: a) a autoridade administrativa; b) o Ministério Público; c) o próprio preso. Logo se constata que a autoridade judiciária da origem não pode agir de ofício, solicitando a transferência de internos. Tal fato, que parece óbvio, na prática, tem sido ignorado. É bem comum encontrar, em processos judiciais de transferência entre estabelecimentos penitenciários, solicitaçóes de transferência formuladas pela própria autoridade judiciária da origem.

Um ponto que merece elogio na lei é o fato de atribuir legitimidade ao próprio preso para requerer transferência para o presídio federal, o que está em conformidade com o princípio da ampla defesa (artigo $5^{\circ}, \mathrm{LV}$ da CF/88) em sua perspectiva de autodefesa. ${ }^{18}$ Tal legitimidade revela-se fundamental, principalmente, nos casos em que os internos correm risco de morte nos seus presídios de origem, o que, infelizmente, é bem comum.

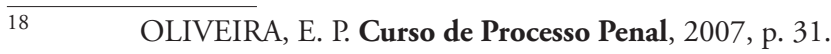


O dispositivo acima transcrito afirma ainda ser necessária a decisão prévia do juiz da origem sobre a transferência do interno, o que acaba revelando um interessante diálogo entre competências jurisdicionais. Desse modo, a Lei acaba por estabelecer um sistema de diálogo entre a competência estadual e a federal, havendo a necessidade de que ambas as esferas jurisdicionais decidam favoravelmente à transferência para que ela possa ser efetivada. Tal entendimento é corroborado pela jurisprudência do Supremo Tribunal Federal:

4. Cabe ao Poder Judiciário verificar se o preso tem ou não o perfil apropriado para a transferência ou a permanência nos presídios federais, em controle compartilhado entre o juízo de origem solicitante e o juízo responsável pelo presídio federal, prevista expressamente em lei forma hábil para a solução de eventual divergência, o conflito de competência (art. $9^{\circ}$ e art. $10, \$ 5^{\circ}$, da Lei no $\left.11.671 / 2008\right) .{ }^{19}$

Ainda no artigo $5^{\circ}$, estabelece-se que caberá à Defensoria Pública da União a assistência jurídica ao preso federal, ponto em que a lei também é digna de elogio, já que também está em conformidade com o princípio da ampla defesa (artigo 5ㅇ, LV da CF/88), agora, sob a perspectiva da defesa técnica. ${ }^{20}$

O papel do Defensor Público Federal é imprescindível no que tange ao acompanhamento de todos os incidentes processuais referentes à permanência ou saída do interno do sistema penitenciário federal, destacando-se: a) a defesa inicial, anterior à inclusão do interno; b) o monitoramento do prazo de permanência estipulado na decisão de inclusão; c) a defesa nos processos disciplinares de interno (artigo 39 e ss. do Decreto 6049).

Não obstante isso, a transferência do interno do sistema estadual para o federal, em lugar distante do da aplicação da pena, tal como é a lógica do sistema, provoca o já citado prejuízo à assistência do Defensor Público Federal, já que os processos criminais da origem tramitaram, em regra, na Justiça Estadual, o que impede atuação do defensor federal, visto que há vários casos de presos provisórios no sistema penitenciário federal, ademais de ser comum existirem vários outros processos em curso na esfera estadual além daquele que levou o interno à prisão e ao sistema federal. Nesses moldes, resta ao Defensor, como já afirmado, solicitar o apoio da Defensoria Estadual na origem, solicitando o acompanhamento do processo criminal inicial.

Conforme o artigo $5^{\circ}, \$ 5^{\circ}$, a decisão que admitir o preso no estabelecimento penal federal

$\overline{19}$ STF - HC 112650 / RJ, rel. Min. ROSA WEBER, 2014.

$20 \quad$ Ibidem, p. 29. 
de segurança máxima indicará o período de permanência, o que será mais bem abordado nos comentários do artigo 10 .

O artigo $5^{\circ}, \$ 6^{\circ}$, possibilita ao juiz federal autorizar a imediata transferência do preso em caso de urgência, o que implica em mais uma utilização de conceito indeterminado em matéria penal, o que não é recomendável. Um ponto bastante relevante é que há entendimento de que tal dispositivo autorizaria o juiz da execução de ofício solicitar a transferência de preso para o sistema federal:

Também o procedimento de transferência do preso para as penitenciárias federais pode ser colocado como um dos casos de manifestação do sistema inquisitório na execução penal. Isto porque, mesmo que a Res. CJF 502 e a Res. CJF 557 (sendo que a segunda surgiu para substituir a primeira), ou a Lei 11.671/2008 (que substituiu ambas as resoluçôes citadas acima), que disciplinam a matéria, façam referência a possibilidade de o processo ser iniciado pelo Ministério Público, pelo preso ou pela administração penitenciária, há o resguardo da possibilidade de o juízo de origem requerer a transferência, agindo de ofício, cabendo, inclusive, suscitar conflito de competência caso seja negado (art. 5, caput, deste último instrumento normativo, bem como a Exposição de Motivos do PL 969/2007, referente à Lei 11.671/2008). ${ }^{21}$

Não obstante o entendimento acima, que critica a ideia de um magistrado poder solicitar a inclusão de ofício de interno no sistema penitenciário federal, aqui, deve-se ser ainda mais rigoroso nesse entendimento para frisar que sequer parece ser semanticamente possível tal entendimento.

$\mathrm{O}$ artigo $5^{\circ}, \$ 5^{\circ}$ apenas autoriza, em casos de extrema necessidade, que o juiz federal possa autorizar a imediata transferência do preso. Neste ponto, deve-se compreender que tal dispositivo implica na possibilidade de o magistrado federal, ante periculum in mora e fumus boni iuris, possa liminarmente decidir pela inclusão de interno no sistema federal, jamais podendo ser extraído disso que o juiz federal ou o juiz estadual possam decretar tal transferência de ofício. Reitere-se: os juízes, nos termos da lei, poderão julgar liminarmente, ou seja, com contraditório diferido, a inclusão de preso no sistema, mas sempre a reboque do pedido de um dos legitimados para isso. Admitir interpretação diversa, realmente, seria possibilitar uma confusão completa entre os papéis de parte e de julgador, ferindo de morte o sistema acusatorial proposto pela Constituição federal de

$\overline{21}$ PACHECO, A. M. P. Sistema Acusatório, Sistema Inquisitivo e Execução nas Penitenciárias de Administração Federal. In: Revista Brasileira de Ciências Criminais, vol. 90, 2011, p. 165 - 187. 
O artigo $6^{\circ}$ ordena que o juízo de origem encaminhe ao juízo federal os autos da execução, quando deferida a transferência do preso condenado, o que é necessário para que o juiz federal possa, nos termos do já comentado artigo $2^{\circ}$, acompanhar a execução penal. O artigo $7^{\circ}$ estatui ser suficiente a carta precatória, remetida pelo juízo de origem, para que o juízo federal competente dê início à fiscalização da prisão no estabelecimento penal federal nos casos de preso provisório.

$\mathrm{O}$ artigo $8^{\circ}$ trata das visitas do juiz corregedor e do membro do Ministério Público, apenas reforçando os comandos já previstos nos artigos 66 e 68 da LEP. Já o artigo $9^{\circ}$, garante ao juízo da origem o poder de suscitar o conflito de competência perante o tribunal competente em caso de negativa de transferência pelo juiz federal. Tal conflito de competência mostra-se equivocado não só terminologicamente, mas também no que diz respeito à legitimidade, já que a autoridade judiciária da origem não é parte legitimada para solicitar transferência como analisado no artigo $5^{\circ}$. Ora, se a autoridade judiciária não possui legitimidade para iniciar o processo de transferência, qual seria a razão jurídica para recorrer da decisão do magistrado federal? Logo nota-se que se alguém deveria recorrer seriam os mesmos legitimados já previstos no artigo $5^{\circ}$.

$\mathrm{O}$ artigo $10^{\circ}$ excluir trata do prazo de permanência de presos no sistema federal e de possíveis renovaçôes de tal período:

Art. 10. A inclusão de preso em estabelecimento penal federal de segurança máxima será excepcional e por prazo determinado.

$\$ 1^{\circ}$. O período de permanência não poderá ser superior a 360 (trezentos e sessenta) dias, renovável, excepcionalmente, quando solicitado motivadamente pelo juízo de origem, observados os requisitos da transferência.

$\$ 2^{\circ}$. Decorrido o prazo, sem que seja feito, imediatamente após seu decurso, pedido de renovação da permanência do preso em estabelecimento penal federal de segurança máxima, ficará o juízo de origem obrigado a receber o preso no estabelecimento penal sob sua jurisdição.

$\$ 3^{\circ}$. Tendo havido pedido de renovação, o preso, recolhido no estabelecimento federal em que estiver, aguardará que o juízo federal profira decisão.

$\$ 4^{\circ}$. Aceita a renovação, o preso permanecerá no estabelecimento 
federal de segurança máxima em que estiver, retroagindo o termo inicial do prazo ao dia seguinte ao término do prazo anterior.

$\$ 5^{\circ}$. Rejeitada a renovação, o juízo de origem poderá suscitar o conflito de competência, que o tribunal apreciará em caráter prioritário.

$\$ 6^{\circ}$ Enquanto não decidido o conflito de competência em caso de renovação, o preso permanecerá no estabelecimento penal federal.

$\mathrm{O}$ artigo acima assevera que a inclusão de preso em estabelecimento penal federal será excepcional e por prazo determinado. Assim sendo, esgotado o prazo de permanência, a medida resta atendida e, diante da excepcionalidade que lhe é inerente, não há motivos para que o interno permaneça no estabelecimento penal federal.

Quanto ao prazo, pode-se ver que o período máximo de permanência no presídio federal é de 360 dias, renovável excepcionalmente, o que significa que pode, inicialmente, ser estipulado um prazo menor, daí a necessidade do artigo $5^{\circ}, \$ 5^{\circ}$, asseverar que decisão que admitir o preso no estabelecimento penal federal de segurança máxima indicará o período de permanência. Tendo em vista que o próprio dispositivo fala que o prazo pode ser renovado excepcionalmente, percebe-se que o real escopo da lei é afirmar que, em cada decisão de renovação, se for o caso, o juiz deve avaliar o novo prazo de permanência nunca podendo tal prazo ser superior a 360 dias por decisão.

Assim sendo, apesar da excepcionalidade da medida, o próprio artigo $10, \$ 1^{\circ}$, afirma que tal prazo pode ser renovado, caso seja solicitado, motivadamente, pelo juízo de origem. Deve-se ainda atentar que o citado parágrafo ressalta a necessidade de que, em um eventual pedido de renovação, sejam atendidos os requisitos da transferência. Neste caso, evidentemente, cabe ao Juiz Federal Corregedor perquirir sobre os motivos que ensejaram o pedido de renovação.

O segundo parágrafo do artigo 10, por sua vez, assevera que, decorrido o prazo determinado para permanência no sistema federal sem o pedido de renovação, ficará o juízo de origem obrigado a receber o preso no estabelecimento penal sob sua jurisdição. Nesses termos, a lei demonstra a excepcionalidade da permanência de interno no sistema federal e, ante a inexistência de pedido de renovação da permanência, impóe o retorno do reeducando ao estabelecimento estadual. Esse entendimento foi consolidado pela Súmula no 8 do "I Workshop dos Juízes Federais Corregedores de Presídios Federais”:

Enunciado no. 8: Decorrido o prazo de dez dias, sem pedido de renovação de permanência, o preso deve ser devolvido, independente- 
mente de qualquer outra providência por parte do juízo. ${ }^{22}$

Ainda quanto à renovação do prazo de permanência, o artigo 10 deve ser interpretado em comunhão com o artigo $5^{\circ}$ da mesma lei, o que significa que, na verdade, os mesmos legitimados a solicitar a transferência devem ser legitimados a requerer a renovação excepcional de permanência do detento. Tal observação decorre da simples lógica jurídica, afinal, conforme o velho e correto brocardo: "onde há a mesma razão, aplica-se o mesmo direito" (ubi eadem ratio legis, ibi eadem legis dispositio).

Dessa maneira, assim como o preso, a autoridade administrativa ou o Ministério Público podem pedir inclusão no sistema penitenciário federal, igualmente, podem solicitar a renovação da permanência, pois os requisitos autorizadores são os mesmos em ambos os casos.

Por fim, o artigo 11 estabelece que a lotação máxima do estabelecimento penal federal de segurança máxima não poderá ser ultrapassada. Recomendando ao magistrado que o número de presos, sempre que possível, permaneça aquém do limite de vagas.

\section{CONSIDERAÇÓES FINAIS}

Ante todo o exposto, constata-se que o sistema penitenciário nacional permanece com graves problemas estruturais, sendo o próprio regime federal a demonstração da falência do sistema penitenciário estadual. Constatam-se também os graves problemas legislativos na regulamentação do regime penitenciário federal, destacando-se o mau uso do poder regulamentar por parte do Executivo.

Ainda no que tange aos problemas de constitucionalidade, o estudo demonstra um vício de constitucionalidade do artigo $2^{\circ}$ da Lei $n^{\circ}$. 11.671/2008, que atribui competência jurisdicional à Justiça Federal, violando a Constituição, que estabeleceu o rol de competências desse segmento judiciário de forma taxativa. Assim sendo, revela-se a necessidade de uma ampla revisão da normatização existente em matéria de execução penal no âmbito federal, devendo-se inclusive pensar em alteraçóes no texto constitucional

$22 \quad$ Disponível em: <http://www.tjsp.jus.br/Download/Corregedoria/Pdf/ ParecerDecisaoCGJTJSPIWorkshopSistemaPenitenciarioFederal.pdf >. Acesso em: 18 fev. 2016. 
para que se possa preservar a atuação da Justiça Federal em execução penal.

Não bastassem tais aspectos, a pobreza normativa da Lei no. 11.671/2008 e os inconstitucionais excessos regulamentares dos decretos comentados obrigam que se realize uma interpretação que confira um mínimo de harmonia ao regime penitenciário federal, o que se buscou nos comentários acima.

Ademais, urge que seja revista a orientação jurisprudencial sobre a matéria, visto que há um excesso de poderes conferidos às autoridades administrativas estaduais no fluxo de internos para o sistema federal, o que é um caminho deveras perigoso ante a precariedade estrutural dos sistemas locais, o que estimula a utilização dos equipamentos federais como mera "válvula de escape", o que, além de contribuir para se perpetuarem as omissóes nos planos estaduais, mina a própria razão de ser do sistema penitenciário federal.

\section{REFERÊNCIAS}

ARRUDA, É. Prisões Federais. Revista do Tribunal Regional da 1a Região, Brasília, v. 22, n. 7, jul. 2010. Disponível em: <http://bdjur.stj.jus.br/dspace/handle/2011/34737>. Acesso em: 13 abr. 2011.

DOTTI, R. A. A trágica colheita dos frutos da omissão. Revista Magister de Direito Penal e Processual Penal, Porto Alegre, v. 2, n. 12, p. 53-57, jun./jul. 2006.

FERNANDES, A. S. Execução Penal: Aspectos jurídicos. Disponível em: <http://daleth. cjf.jus.br/revista/numero7/artigo8.htm>. Acesso em: 14 abr. 2011.

GRECO, R. Curso de Direito Penal: Parte geral. v. 1. Niterói: Impetus, 2009.

GRINOVER, A. P.; GOMES FILHO, A. M.; FERNANDES, A. S. Recursos no Processo Penal. 6.ed. São Paulo: Revista dos Tribunais, 2011.

MARCÃO, R. Curso de Execução Penal. 5.ed. São Paulo: Saraiva, 2007.

OliVeIRA, E. P. Curso de Processo Penal. 8.ed. Rio de Janeiro: Lúmen Juris, 2007. 
PACHECO, A. M. P. Sistema Acusatório, Sistema Inquisitivo e Execução nas Penitenciárias de Administração Federal. In: Revista Brasileira de Ciências Criminais, vol. 90/2011, p. 165-187, Mai-Jun/2011 DTR\2011\1581. P. 4.

PENTEADO JUNIOR, A. T. O Sistema Penitenciário Federal. Revista Magister de direito penal e processual penal, Porto Alegre, v. 35, 2004. Disponível em: < http:// docs.exdat.com/docs2/index-625533.html>. Acesso em: 18 fev. 2016.

Resolução do CJF sobre os novos presídios federais. Superior Tribunal de Justiça, Brasília, 10 mai. 2006. Disponível em: <http://www.stj.jus.br/sites/STJ/default/pt_BR/noticias/ noticias/\%C3\%9Altimas/Publicada-resolu\%C3\%A7\%C3\%A3o-do-CJF-sobre-osnovos--pres\%C3\%ADdios-federais>. Acesso em: 18 fev. 2016.

ROCHA, J. B. In: A Defensoria como custös vulnerabilis e a advocacia privada. Disponível em: <http://www.conjur.com.br/2017-mai-23/tribuna-defensoria-defensoriacustos-vulnerabilis-advocacia-privada>. Acesso em: 26 mai. 2017.

TRAFICANTE Juan Carlos Abadia é preso pela PF em SP. Terra. Disponível em: $<$ http://noticias.terra.com.br/retrospectiva2007/interna/0,,OI2121900-EI10676,00. html>. Acesso em: 18 fev. 2016. 